\title{
Importance of Lowered Ionized Magnesium Concentrations in Elderly Hypertensives
}

\author{
K Kisters ${ }^{1,2 *}$, F Wroblewski ${ }^{1,2}$, A Deutsch ${ }^{2}$, L Kisters ${ }^{2}$, U Gröber ${ }^{2}$ and T Westhoff ${ }^{3}$ \\ ${ }^{1}$ Med Clinic I, St. Anna Hospital, Germany \\ ${ }^{2}$ Society for Magnesium Res, Germany \\ ${ }^{3}$ Med Clin I, Ruhr-Universität Bochum, Germany
}

*Corresponding author: K Kisters, Medizinische Klinik I, St. Anna Hospital, 44649 Herne, Hospitalstr 19, Society for Magnesium Res, Tutzing, Germany.

To Cite This Article: K Kisters, Importance of Lowered Ionized Magnesium Concentrations in Elderly Hypertensives. 2020 - 7(4). AJBSR. MS.ID.001172. DOI: 10.34297/AJBSR.2020.07.001172.

Received: 眥 February 14, 2020; Published: 眥 February 24, 2020

\section{Introduction}

In recent publications a magnesium deficiency in elderly is up to $50 \%$, depending on co-morbidity, drugs and nutritional status $[1,2]$. On the other hand, it is well known that a magnesium insufficiency is a pathogenic factor in the development of primary hypertension [2-11]. In this context calcium magnesium antagonism, sodium magnesium antiport, disturbed vitamin D metabolism or disturbed magnesium channels (TRPM 6 and 7) are of special interest [1-7]. For these reasons magnesium metabolism was of interest in elderly hypertensives. Ionized magnesium is the active form and was measured additionally. Up to now it is not clear whether there is a correlation between plasma or serum magnesium concentrations and ionized magnesium content.

Therefore, we investigated 45 essential hypertensives patients with normal renal function. None of the patients received diuretics or magnesium. No diabetics were included. The age of patients was beyond 65 years, 23 persons were male, 22 females.

Measurements of magnesium were performed either in serum (Cobass, Roche, Germany) or ionized in blood (NOVA, Rödermark, Germany).

In serum magnesium concentrations only 1 person had values below $1.5 \mathrm{mg} / \mathrm{dl}$, all other elderly hypertensives had a normal serum magnesium concentration.

In contrast ionized magnesium concentrations was significantly decreased in 15 of 45 patients, showing values below $0,5 \mathrm{mmol} / \mathrm{l}$ $(\mathrm{p}<0.01)$, that is $30 \%$.
In addition, no correlation between total serum and ionized blood magnesium exists (ns., Pearson or Spearmann rank test, $\mathrm{p}$ value 0.91 and 0.41 ) (Figure 1). Blood pressure was controlled and below $150 / 90 \mathrm{mmHg}$. The data presented here show that there is no correlation between serum and ionized blood magnesium content. This is of special importance as a normal serum magnesium content doesn't exclude a deficiency of ionized magnesium. As ionized magnesium is the vasoactive form of magnesium in the body and acts on vessels, it is more useful to determine ionized magnesium concentrations in assessing body magnesium stores. In elderly hypertensives under blood pressure control nearly $30 \%$ showed an ionized magnesium deficiency despite normal serum magnesium values.

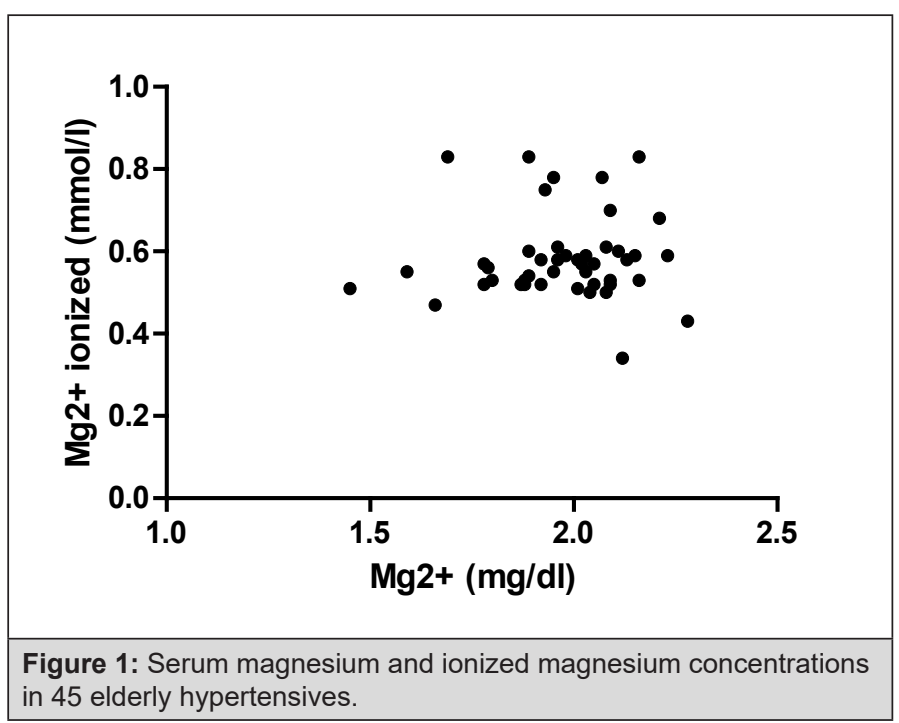




\section{References}

1. Gröber U, Schmidt J, Kisters K (2015) Magnesium in Prevention and Therapy. Nutrients 7(9): 8199-81226.

2. Gröber U, Schmidt J, Kisters K (2020) Important drug-micronutrient interactions: A selection for clinical practice. Crit Rev Food Sci Nutr 60(2): 257-275.

3. Kisters K, Gröber U (2018) Magnesium and thiazide diuretics. Magnes Res 31(4): 143-145.

4. Kisters K, Gremmler B, Schmidt J, Gröber U, Tokmak F (2017) Positive effect of magnesium orotate therapy in hypertension heart disease. Metabolomics 7(3): 1-4.

5. Rosanoff A, Plessert MR (2013) Oral magnesium supplements decrease high blood pressure $(\mathrm{SBP}<155 \mathrm{mmHg})$ in hypertensive subjects on antihypertensive medications: a targeted meta-analysis. Magnes Res 26(3): 93-99.

6. Touyz RM, Yao G, G yao (2004) Presence of functionally active $\mathrm{Mg}^{2+}$ uptake channels, TRPM6 and TRPM7 in vascular smooth muscle cell from WKY and SHR- differential regulations by aldosterone an angiotensin II. Am J Hypertension 17(5):176.
7. Vorman J (2016) Magnesium: Nutrition and Homoeostasis. AIMS Public Health 3(2): 329-340.

8. Kisters K, Tepel M, Spieker C, Dietl KH, Barenbrock M, et al. (1997) Decreased cellular magnesium concentrations in a subgroup of hypertensives--cell models for the pathogenesis of primary hypertension. J Hum Hypertens 11(6): 367-372.

9. Kisters K, Tepel M, Spieker C, Zidek W, Barenbrock M, et al. (1998) Decreased membrane $\mathrm{Mg}^{2+}$ concentrations in a subgroup of hypertensives: membrane model for the pathogenesis of primary hypertension. Am J Hypertens 11(11 Pt 1): 1390-1393.

10. Kisters K, Krefting ER, Spieker C, Zidek W, Dietl KH, et al. (1998) Increased sodium/magnesium exchange in vascular smooth muscle cells. SHR Clin Sci 95: 583-587.

11. Kisters K, Gröber U (2013) Magnesium in health and disease. Plant and Soil 368: 155-165. 